\title{
"Bitter" manioc (Manihot esculenta): its consumption and the grater used by the indigenous peoples of the Gran Chaco in its preparation
}

Le manioc "amer " (Manihot esculenta) : sa consommation et la râpe utilisée pour sa préparation chez les Indiens du Gran Chaco La mandioca "amarga" (Manihot esculenta): su consumo y el rallador empleado para su preparación entre indígenas del Gran Chaco

Nicolás M. Kamienkowski and Pastor Arenas

\section{OpenEdition}

\section{Journals}

Electronic version

URL: https://journals.openedition.org/jsa/15230

DOI: $10.4000 /$ jsa. 15230

ISSN: 1957-7842

Publisher

Société des américanistes

Printed version

Date of publication: 15 December 2017

Number of pages: 205-228

ISSN: 0037-9174

Electronic reference

Nicolás M. Kamienkowski and Pastor Arenas, "'Bitter" manioc (Manihot esculenta): its consumption and the grater used by the indigenous peoples of the Gran Chaco in its preparation", Journal de la Société des américanistes [Online], 103-2 | 2017, Online since 15 December 2017, connection on 26 September 2022. URL: http://journals.openedition.org/jsa/15230 ; DOI: https://doi.org/10.4000/jsa. 15230 


\title{
"Bitter" manioc (Manihot esculenta): its consumption and the grater used by the indigenous peoples of the Gran Chaco in its preparation
}

\author{
Nicolás M. KAMIENKOWSKI and Pastor ARENAS *
}

This paper discusses the cultivation of "bitter" manioc (Manihot esculenta) by the ethnic groups of the Gran Chaco, the preparing for consumption, and also the grater used in the process. It includes a bibliographical review on the subject, and the results of a study made of the graters in different ethnographic museums around the world. Field investigations provided clear evidence of cultivation of the plant, the way in which it was prepared and consumed, as well as the characteristics of the grater. They confirmed consumption of "bitter" manioc by the Maká, Nivaclé, Lengua-Maskoy and Choroti-Manjuy peoples, the steps in preparing it and the peculiarities of the grater used. This plant, the way in which it was cooked and the use of the grater are now practically lost among the ethnic groups of the Gran Chaco. [Key words: edible plants, agriculture, material culture, indigenous knowledge, ethnobotany, cuisine.]

Le manioc « amer » (Manihot esculenta) : sa consommation et la râpe utilisée pour sa préparation chez les Indiens du Gran Chaco. Cet article documente la culture du manioc « amer» (Manihot esculenta) par les groupes ethniques du Gran Chaco, la préparation pour sa consommation et la râpe utilisée pour son élaboration. Une revue de la littérature sur le sujet est proposée, ainsi que la présentation d'une collection de râpes appartenant à divers musées ethnographiques dans le monde. Au cours d'enquêtes sur le terrain, nous avons constaté la présence de la plante domestiquée, documenté sa préparation, sa consommation, ainsi que les caractéristiques de la râpe. Cette recherche a permis de confirmer la consommation du manioc « amer», les détails de sa préparation, ainsi que les particularités de la râpe chez les indiens Maká, Nivaclé, Lengua-Maskoy et Choroti-Manjuy. Actuellement cette plante cultivée a presque disparu chez les groupes ethniques du Gran Chaco, comme les pratiques culinaires qui lui sont associées et l'utilisation de la râpe. [Mots-clés : plante comestible, agriculture, culture matérielle, connaissance indigène, ethnobotanique, cuisine.]

* CEFyBO-Conicet, Facultad de Medicina, Universidad de Buenos Aires (UBA), Argentina [nicokam@gmail.com, pastorarenas@yahoo.com.ar]. 
La mandioca "amarga" (Manihot esculenta): su consumo y el rallador empleado para su preparación entre indigenas del Gran Chaco. Este trabajo documenta el cultivo de la mandioca "amarga" (Manihot esculenta) entre grupos étnicos del Gran Chaco, la preparación para su consumo y al rallador aplicado para su elaboración. Se realizó una revisión bibliográfica sobre el tema y se consultaron las colecciones de ralladores pertenecientes a diversos museos etnográficos del mundo. En entrevistas realizadas durante el trabajo de campo, se pudo comprobar la presencia de dicho cultígeno, su modo de preparación y consumo, así como las características del rallador. Se confirma el consumo de la mandioca "amarga" entre los Maká, Nivaclé, Lengua-Maskoy y Choroti-Manjuy, así como los pasos detallados para su preparación y las peculiaridades del rallador empleado. En la actualidad prácticamente se ha perdido dicho cultígeno entre los grupos étnicos del Gran Chaco, y más aún su práctica culinaria, así como el uso del rallador. [Palabras clave: plantas comestibles, agricultura, cultura material, conocimiento indígena, etnobotánica, culinaria.]

The indigenous peoples of the Gran Chaco are traditionally hunters-fishersgatherers, and they also practice basic agriculture, focusing on a small number of crops (Métraux 1946, p. 246-260; Palavecino 1948, p. 19-24; Zerries 1968, p. 360; Cordeu and de los Ríos 1982, p. 131-137; Braunstein and Miller 1999, p. 1-7). One of the least known of the plants they grew is "manioc" (Manihot esculenta Crantz, Euphorbiaceae) in its numerous varieties and horticultural forms. In the past, the "bitter" or "poisonous" variety seemed to be the most common in the region. Today, however, it has almost completely disappeared from indigenous vegetable gardens, having been replaced by the "sweet" variety, as a result of contact with the Criollo people. A series of techniques was used in preparing "bitter" manioc, and a specific utensil served to grate the roots and allow the pulp, or solid portions, to be separated from the toxic liquid. The following account is based on field investigations, observations of pieces preserved in ethnographic museums and a review of bibliographic sources.

Nordenskiöld (1912, p. 56; 1929a, p. 90) is the sole author to have spoken of the "bitter" manioc grater among the ethnic peoples of the Gran Chaco. He provides a photograph of this artifact and describes how the Choroti and the Nivaclé peoples used it, information which was later repeated by other authors (Métraux 1946; Susnik 1982). Several decades passed before Arenas (1981, 1982, 1983) was able to document the use of this object by the Lengua-Maskoy and the Maká peoples. This paper also reveals the existence of the artifact among the Choroti who live in the forest (the Manjuy of Paraguay), and provides new data to add to existing information on the Nivaclé, also from the Paraguayan Chaco.

The "bitter" manioc grater of the Gran Chaco is usually made with elements of plant origin (woods and spines), but on occasions metal plates are used instead. Although the grater has now almost completely fallen into disuse, in the field one of the authors (Arenas) was still able to record its use. 
Nordenskiöld (1929a, p. 33) suggested that the cultivation of horticultural plants in the Gran Chaco was a relatively recent development, since the two peoples he studied (Choroti and Nivaclé) lived mainly from gathering and fishing, and agriculture seemed not to have been a longstanding practice. The author believed that it was the Arawak indigenous peoples who introduced agriculture into the Gran Chaco. In fact, in pre-Columbian times sedentary agricultural societies speaking a language from the Arawak linguistic family lived near the north-east and north-west frontiers of the Gran Chaco. They were known as "Chaná," "Chané" or "Guaná" and were the southernmost members of the scattered Arawak linguistic family, whose traditional homeland was in the north of Amazonia (Figure 1, see next page). These Arawak groups were subjugated by the native peoples of the Gran Chaco, coexisted with them and brought to the region a great many elements of their culture, including horticulture (Métraux 1946, p. 238-241; Kersten 1968, p. 107-114). As for the subject of this paper, Nordenskiöld (1929a, p. 33) speculated that the practice of growing manioc and the grater were brought to the Gran Chaco by ethnic peoples from regions to the north and east.

Among the indigenous agricultural groups of South America one of the most widespread and ancient crops grown is manioc, also known as "yuca" or "cassava" (Schmidt 1951, p. 241-242; Renvoize 1972, p. 352). Except among the ethnic groups of the Gran Chaco, both "bitter" manioc and the "sweet" variety, as well as a continuum of varieties, are still cultivated in other regions of the Neotropics. Given the crop's socioeconomic importance, new contributions made from a variety of approaches are permanently emerging in various scientific fields. They deal with the center of origin and dispersal; systematics and ethnosystematics; evolution; the phenotypic qualities of the different varieties of manioc; phytochemicals; conservation and handling; and cultural, economic and social aspects (Schwerin 1970, 1971; Renvoize 1972; Boster 1985; Nye 1991; Salick et al. 1997; Elias et al. 2000, 2004; Emperaire 2000-2004; Allem 2002; Wilson and Dufour 2002; Peroni et al. 2007; Emperaire et al. 2008; Rival and McKey 2008; Bradbury et al. 2013; Santos Mühlen et al. 2013). There has been a longstanding interest in discovering the region in which manioc was originally domesticated and different hypotheses have been put forward (Renvoize 1972, p. 359; Allem 2002, p. 11-12, fig. 1.4). It is now assumed that it occurred in certain areas of neotropical South America, possibly in humid zones of the Brazilian Amazonia (Allem 2002, p. 11-12, fig. 1.4).

The most common varieties of manioc are the "sweet" variety and a "bitter" or "poisonous" one (Rogers and Fleming 1973). The toxicity of both varieties is due to the presence of cyanogenic glycosides in the plant's tissues. However, variations in the degree of toxicity between the different varieties of manioc lie on a continuum, meaning that such a characteristic lacks taxonomic validity, although it is important when considering nutritional aspects. Likewise, 


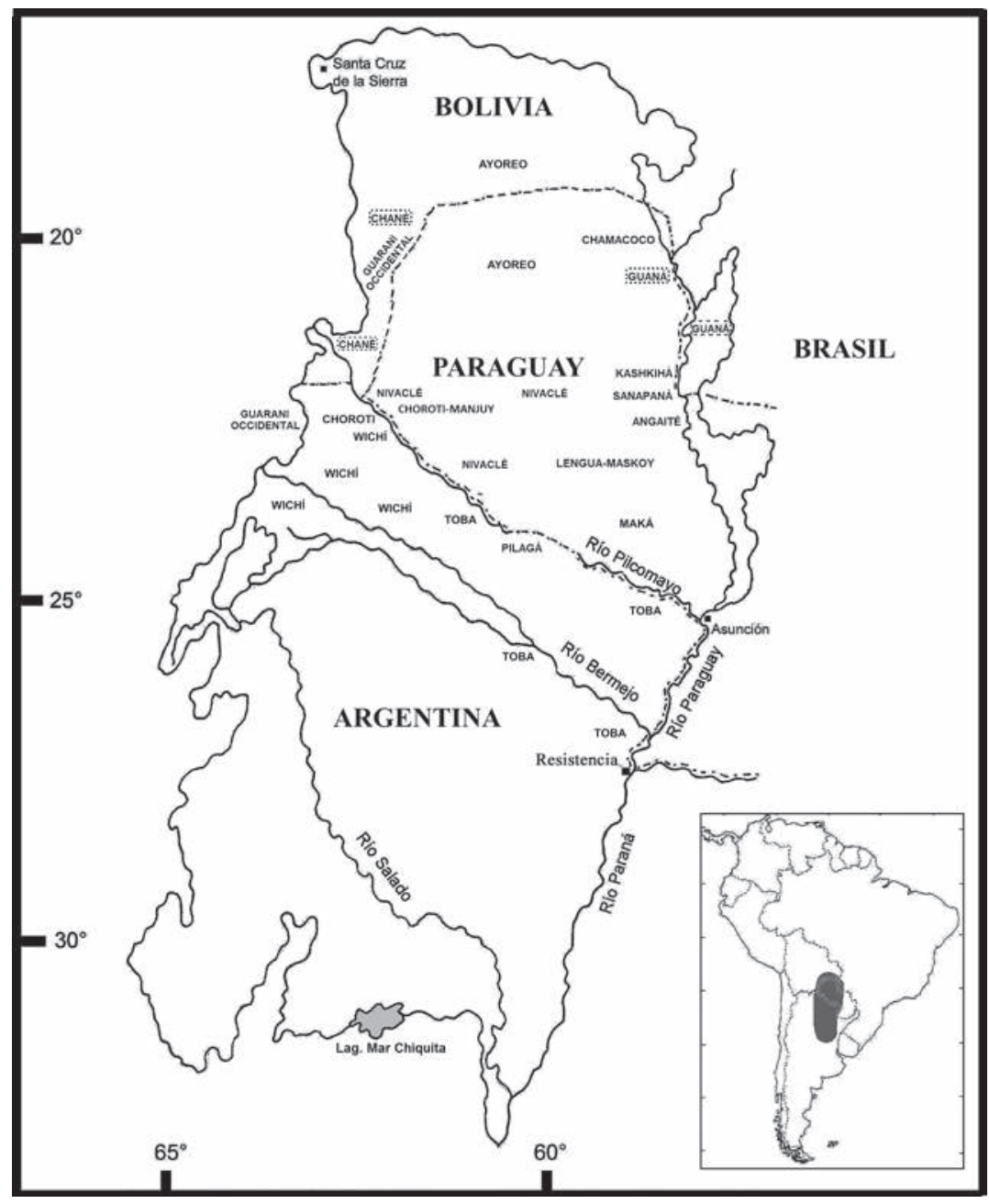

Fig. 1 - Location of the ethnic groups of the Gran Chaco mentioned. The ethnic groups that have disappeared appear within the dotted line.

Manihot esculenta includes a high number of distinguishable morphological variations, which, with their respective folk names, are recognized by the people but which also lack validity for botanical taxonomy (Renvoize 1972, p. 358; Rogers and Fleming 1973, p. 8; Boster 1985; Nye 1991; Emperaire 2000-2004; Allem 2002; Emperaire et al. 2008; Bradbury et al. 2013).

This paper provides information on the growing of "bitter" manioc and the use of the grater in its preparation among the ethnic groups of the Gran Chaco, and includes an investigation into the morphology of the artifact, the raw materials 
involved and the form of use. It thus takes a new look at a topic dealt with almost a century ago by Nordenskiöld (1912, 1929a), which later authors have barely mentioned. Two motives underlie this work: one is the dearth of bibliographic information on "bitter" manioc, and data on its use and on the grater in the Gran Chaco; the other is the fact that there are very few graters made by ethnic peoples in the region to be found in ethnographic museums around the world, particularly in those that have collections from South America. This contribution does not seek to review or update the multiple fields that involve manioc as a crop in the Neotropics.

\section{Methodology}

This paper is based on the ethnobotanical research conducted among the indigenous peoples of the Gran Chaco since 1974. From the outset, fieldwork was based on the use of an ad hoc survey which became richer and more finely tuned with each campaign until a general survey was finally standardized (Arenas 1995). The manioc grater always featured in the items on agriculture, food and material culture in these surveys. During the field investigations the use of graters was observed among three ethnic groups (Lengua-Maskoy, Nivaclé and Choroti-Manjuy).

The information obtained in the field is expanded and contrasted by means of an exploration of bibliographic sources that provide evidence of the presence of "bitter" manioc in the Gran Chaco, its preparation and consumption, as well as the use of the grater. A review is also made of the data recorded on index cards and in photographs of pieces that feature in the catalogs of museums housing collections from the Gran Chaco, as well as from other regions of South America where the utensil is used. In order to locate the manioc graters, various museum search terms were entered for the plant and for the instrument, both in the official language of the museum and in English. Whenever possible, we contacted the curators or those persons responsible for the collections by email, to ensure the best possible access to the data. The museums consulted were: the Museum der Kulturen (Basel), the Göteborgs Etnografiska Museum (Göteborg), the Museo Etnográfico "Juan B. Ambrosetti” (Buenos Aires), the Musée du Quai Branly (Paris), the Ethnologisches Museum (Berlin), the Weltmuseum (Vienna), the National Museum of Natural History, Smithsonian Institution (Washington), the Peabody Museum of Archaeology and Ethnology (Harvard University, Cambridge), the Pitt Rivers Museum (Oxford), the Field Museum of Natural History (Chicago), the Museum Volkenkunde (Leiden), the Musée d'ethnographie (Geneva) and the Museu do Índio (Rio de Janeiro). Only in the Museo Etnográfico "Juan B. Ambroseti" could two graters from the Nivaclé of the Gran Chaco, of which a description is given, be studied in situ. 


\section{Results}

References to the cultivation and use of manioc by the ethnic peoples of the Gran Chaco are scarce and rather vague. In most cases it is not clear whether they refer to the "sweet" or the "bitter" variety, and no details are given as to the form of preparation and use, the extension of the area under cultivation, or other aspects of the activity (soils, growing seasons, technology involved, etc.). Similarly, references to the grater are rare. One of the oldest pieces of data on the growing of manioc was provided by the Spanish traveler Félix de Azara at the end of the 18th century. He speaks of the Guaná, a sedentary group of Arawak filiation that lived from agriculture. Unfortunately, he does not specify the variety of manioc involved (Azara 1904, p. 384).

Cardus (1886, p. 273) refers to the Zamuco (probably the present-day Ayoreo) as small cultivators and, among the crops sown, he records manioc. ${ }^{1}$ At the start of the 20th century, carefully tended manioc patches were observed among the Choroti, the Nivaclé (the latter also called Ashlushlay or Chulupí) and also perhaps the Wichí, but no indication is given as to the variety involved (Nordenskiöld 1912, p. 46; 1929a, p. 9, 33; Von Rosen 1924, p. 111). Interestingly, Métraux (1946, p. 251) mentions that "sweet" manioc was one of the most widespread crops in the Gran Chaco, and he recorded the presence of "bitter" manioc only among the Guaná.

From the start of the 20th century several reliable ethnographic references mention that manioc was grown by different ethnic groups, without specifying the variety or adding other details. These data mention the Machicui (Lengua, Sanapaná and Angaité) (Boggiani 1900, p. 39), Maká (Kisela 1931-1932, p. 45), Kashkihá and Chamacoco peoples in Alto Paraguay (Baldus 1931, p. 34-37). Later ethnographic and ethnobotanical research provided more specific information about the crop. On the basis of the fieldwork undertaken it was observed that the ethnic groups do not speak of the "bitter"/“sweet" classification, but do distinguish between a poisonous manioc and another, innocuous one. To facilitate comprehension of the text, we shall use the corresponding "bitter" or "sweet" denomination, as habitually used in the scientific literature. The Lengua-Maskoy liked to cultivate "bitter" manioc, and their lexicon includes the names of numerous varieties. They also consumed the "sweet" variety, obtained from contact with the Criollo population and from the Mennonites, who arrived in the first decades of the 20th century. The fact that the "sweet" manioc was foreign is reflected in the name given, which can be translated as “white man's manioc" (Arenas 1981, p. 227-228; Stahl 1982, p. 39). "Bitter"

1. Later ethnographic work, however, has not been able to confirm that the Ayoreo grew manioc (Bórmida and Califano 1978; Mashnshnek 1989). Schmeda-Hirschmann (1998, p. 12-13) mentions that it was grown in mission settlements as a result of outside influence. 
manioc continued to be grown by the Nivaclé throughout the 20th century (Stahl 1982, p. 49, 54; Chase Sardi 2005, p. 236-237). Field research in 2014 and 2015 revealed that they were still using it until a few decades ago. Similar data are mentioned in reference to the Maká, who once cultivated both varieties, although "sweet" manioc was less common. Today, this is the only variety grown, while the "bitter" one has disappeared (Figure 2a; Arenas 1982, p. 221222). The Manjuy, a group of Choroti who live in the Paraguayan forest, were seen to have plantations of "bitter" manioc, which they were still eating in the 1980s. Nevertheless, this variety is practically grown no longer (Figure 2b).

\section{"Bitter" manioc preparation in the Gran Chaco}

The different forms of preparing "bitter" manioc used by the indigenous peoples of the Gran Chaco are described below. They are based on information obtained during interviews with persons who were familiar with the practice, and who had gained experience at times when it was still carried out. The data were collected from the Nivaclé, the Lengua-Maskoy, the Maká and the Choroti-Manjuy. Among the last-mentioned group the complete preparation process could be observed and documented (Figure 3, see next page).

The preparation process for manioc requires three utensils: a grater, a sieve in which the grated "bitter" manioc is collected, and a receptacle to collect the
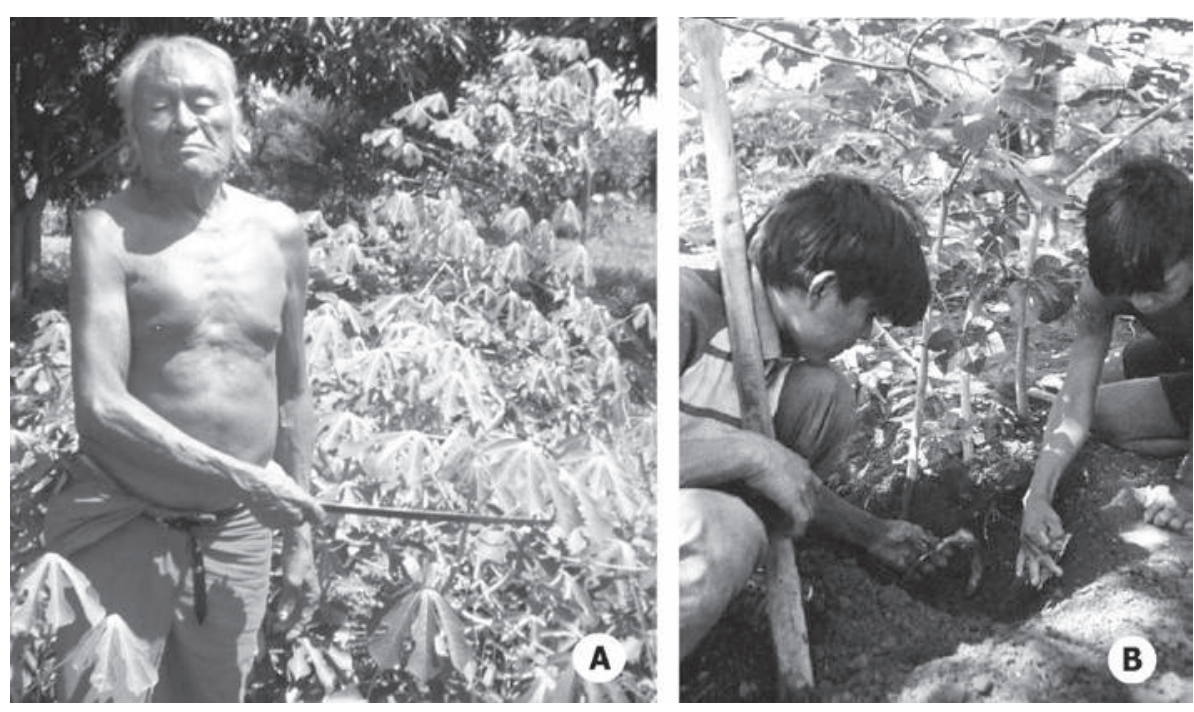

Fig. 2 - a. Maká man and a "bitter" manioc plant (Colonia Fray Bartolomé de las Casas, Paraguay, XII-1978, Photographer: P. Arenas); b. ChorotiManjuy Indians extracting "bitter" manioc roots with the aid of a digging stick (Misión Santa Rosa, Paraguay, II-1981, Photographer: P. Arenas). 


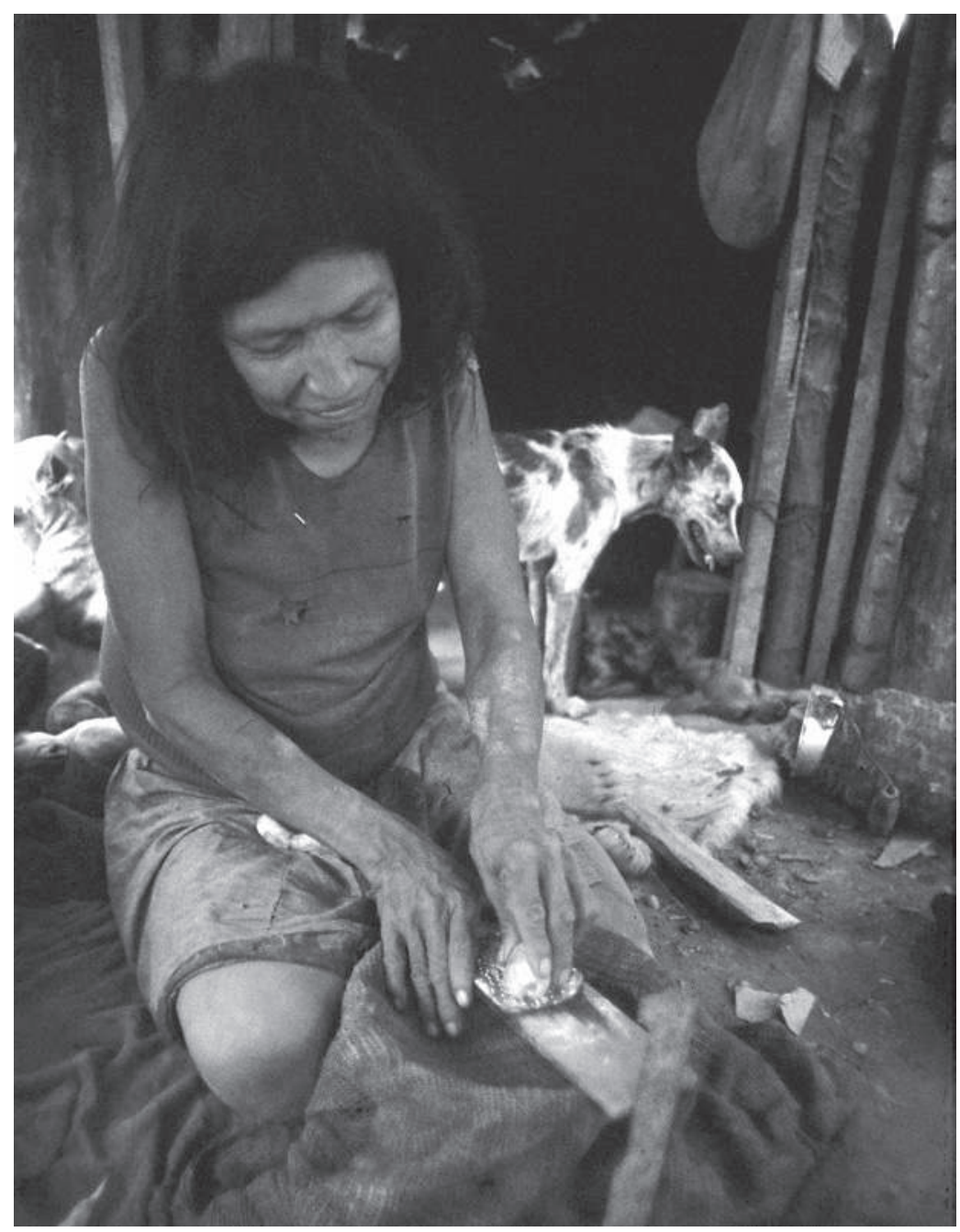

Fig. 3 - Choroti-Manjuy woman processing a "bitter" manioc root with a tin grater and a wooden base over a fiber bag that acts as a sieve (Misión Santa Rosa, Paraguay, II-1981, Photographer: P. Arenas).

liquid produced during grating. The first step consists in washing and peeling the roots, and then grating them. The grater is held firm against a stick or rod above a sieve. Below is the receptacle which collects the liquid resulting from shredding the fleshy tissues of the manioc. After grating, the mash or pulp from the root is either squeezed by hand or pressed through the sieve, so as to extract the greatest quantity of juice possible. At the end of this procedure two products are obtained: a liquid portion and a solid one. 
The liquid portion in the receptacle is left to decant, leaving a floury white sediment that is separated by hand: one part remains with the liquid and the other is mixed into the mash once again. This liquid portion, together with the remaining sediment, is then stirred and put to boil for a considerable length of time, when it takes on a milky aspect. Fresh bean grains (Phaseolus vulgaris, Fabaceae) or pieces of sweet potato roots (Ipomoea batatas, Convolvulaceae) are often added. This process is usually carried out at night so that it can be consumed the following morning at breakfast, now tasting sweet. The liquid portion needs to be boiled for a length of time known to the person preparing it; if uncooked or inadequately prepared, consumption of "bitter" manioc is thought to be dangerous and toxic.

The solid portion is dried in the sun, and is then added to broths, or it is cooked immediately by placing it either over embers or among the ashes, near the fire. This mass can be consumed directly as bread or it can be added to broths. Alternatively, it can be stored for later consumption (Figure 4).

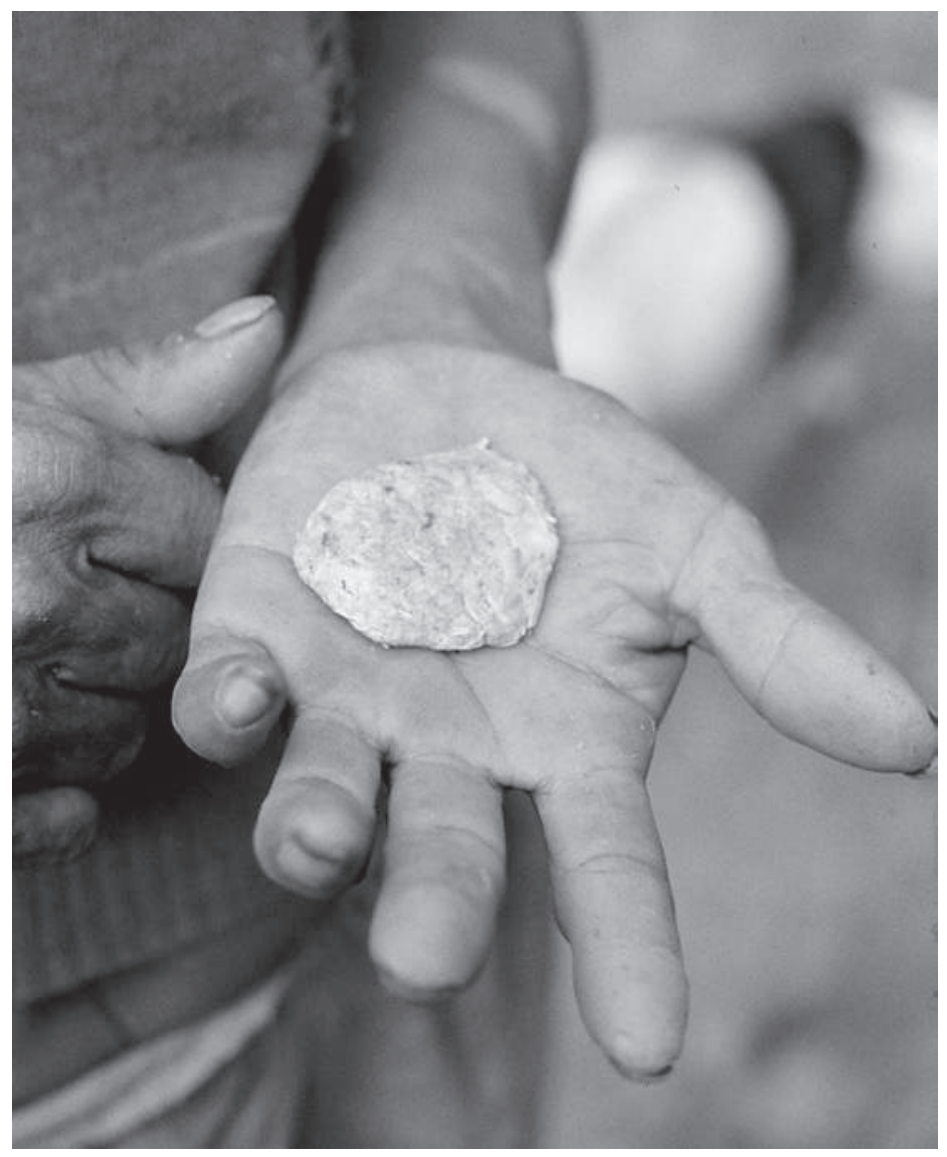

Fig. 4 -

Choroti-

Manjuy woman preparing bread from grated "bitter" manioc roots (Misión Santa Rosa, Paraguay, II-1981, Photographer: P. Arenas). 
The sieve could be an old fine mesh bag of Bromelia urbaniana (Bromeliaceae) fibers, a cloth or other piece of fabric. The receptacle used to collect the liquid was generally of pottery or gourd (Lagenaria siceraria, Cucurbitaceae), but in later years, these receptacles were replaced by others of industrially produced plastic or metal.

\section{The "bitter" manioc grater in the Gran Chaco}

The graters documented among the ethnic peoples of the Gran Chaco are described below. The instrument was observed in situ among the ChorotiManjuy, the Lengua-Maskoy and the Nivaclé. Oral information was collected on the artifact from the Maká, as well as from the peoples mentioned above. Two pieces made by the Nivaclé were studied in the Museo Etnográfico "Juan B. Ambrosetti" (Buenos Aires). In addition to these data, there are photographs in databases in the following museums: a Lengua grater at the Pitt Rivers Museum (Oxford), a Nivaclé (Ashlushlay) grater at the Göteborgs Etnografiska Museum (Göteborg) and a Nivaclé grater at the Museum der Kulturen (Basel). A summary of the data appears in Figure 5.

\begin{tabular}{|c|c|c|c|}
\hline \multirow{2}{*}{ Ethnic group } & \multicolumn{3}{|c|}{ Manioc grater } \\
\hline & Morphology & Base & Tooth \\
\hline \multirow[b]{2}{*}{ Choroti-Manjuy } & \multirow{2}{*}{$\begin{array}{l}\text { Rectangular piece of } \\
\text { wood }(60 \times 15 \mathrm{~cm} \\
\text { approx. })\end{array}$} & \multirow[b]{2}{*}{$\begin{array}{l}\text { Stetsonia coryne or } \\
\text { Salta triflora wood }\end{array}$} & $\begin{array}{c}\text { Spines of Cereus } \\
\text { stenogonus }\end{array}$ \\
\hline & & & $\begin{array}{l}\text { Toothed metal plate } \\
\text { held in place by nails, } \\
\text { cord or the fingers }\end{array}$ \\
\hline \multirow{2}{*}{ Lengua-Maskoy } & $\begin{array}{l}\text { Piece of wood (40 cm } \\
\times 15 \mathrm{~cm} \text { approx. with } \\
\text { rounded ends) }\end{array}$ & \multirow{2}{*}{$\begin{array}{c}\text { Sectioned Stetsonia } \\
\text { coryne wood }\end{array}$} & $\begin{array}{l}\text { Spines of Cereus } \\
\text { stenogonus }\end{array}$ \\
\hline & $\begin{array}{l}\text { Piece of wood (no } \\
\text { data regarding } \\
\text { measurements) }\end{array}$ & & Toothed metal plate \\
\hline Lengua-Maskoy ${ }^{\mathrm{a}}$ & $\begin{array}{l}\text { Rectangular piece of } \\
\text { wood }(62.2 \times 10 \mathrm{~cm})\end{array}$ & $\begin{array}{c}\text { Stetsonia coryne } \\
\text { wood }\end{array}$ & $\begin{array}{c}\text { Spines of Trithrinax } \\
\text { schizophylla } \\
\text { (Arenas 1981, p. 80) }\end{array}$ \\
\hline \multirow{3}{*}{ Maká } & $\begin{array}{c}\text { Piece of wood (40 } \\
\times 15 \mathrm{~cm} \text { approx.) car- } \\
\text { ved on one of its sides }\end{array}$ & $\begin{array}{c}\text { Prosopis kuntzei or } \\
\text { Bulnesia sarmien- } \\
\text { toi } \text { wood }\end{array}$ & Furrowed surface \\
\hline & $\begin{array}{l}\text { Cross-section of whole } \\
\text { wood or piece of wood } \\
(40 \times 15 \mathrm{~cm} \text { approx. })\end{array}$ & $\begin{array}{c}\text { Stetsonia coryne } \\
\text { wood }\end{array}$ & $\begin{array}{l}\text { Gleditsia amor- } \\
\text { phoides spines }\end{array}$ \\
\hline & $\begin{array}{l}\text { Piece of wood (no } \\
\text { data regarding } \\
\text { measurements) }\end{array}$ & Wood (unspecified) & Toothed metal plate \\
\hline
\end{tabular}




\begin{tabular}{|c|c|c|c|}
\hline \multirow{2}{*}{ Nivaclé } & $\begin{array}{c}\text { Piece of wood carved } \\
\text { on one of its sides }\end{array}$ & $\begin{array}{c}\text { Bulnesia sarmien- } \\
\text { toi or Schinopsis } \\
\text { lorentzii wood }\end{array}$ & Furrowed surface \\
\cline { 2 - 4 } & $\begin{array}{c}\text { Piece of wood (no } \\
\text { data regarding } \\
\text { measurements) }\end{array}$ & $\begin{array}{c}\text { Sectioned Stetsonia } \\
\text { coryne wood }\end{array}$ & $\begin{array}{c}\text { Toothed metal plate } \\
\text { held in place by } \\
\text { Bromelia urbaniana } \\
\text { cord and nails }\end{array}$ \\
\hline Nivacléb & $\begin{array}{c}\text { Piece of wood with } \\
\text { handles at both ends }(80 \\
\times 15 \mathrm{~cm})\end{array}$ & $\begin{array}{c}\text { Wood, possibly } \\
\text { Stetsonia coryne }\end{array}$ & $\begin{array}{c}\text { Toothed metal plate } \\
\text { held in place by cord } \\
\text { and nails }\end{array}$ \\
\cline { 2 - 4 } $\begin{array}{c}\text { Nivacle } \\
\text { (Ashlushlay) }\end{array}$ & $\begin{array}{c}\text { Piece of wood with its alba } \\
\text { narrowed ends forming } \\
\text { two handles (no mea- } \\
\text { sures specified) }\end{array}$ & $\begin{array}{c}\text { Palm tree wood } \\
\text { (unspecified) }\end{array}$ & $\begin{array}{c}\text { Wooden chips in the } \\
\text { center }\end{array}$ \\
\hline Nivacléd & $\begin{array}{c}\text { Wood sectioned in the } \\
\text { middle }(60 \times 11 \mathrm{~cm})\end{array}$ & $\begin{array}{c}\text { Stetsonia coryne } \\
\text { wood }\end{array}$ & $\begin{array}{c}\text { Toothed metal plate } \\
\text { held in place by nails }\end{array}$ \\
\hline
\end{tabular}

Fig. 5 - Graters documented in situ, described in interviews and observed in museums.

References: a. Pitt Rivers Museum (University of Oxford), b. Museo Etnográfico "Juan B. Ambrosetti” (Buenos Aires), c. Göteborgs

Etnografiska Museum (Göteborg), d. Museum der Kulturen (Basel).

\section{Graters documented in situ}

The Choroti-Manjuy report that they used to make the grater with a rectangular flat piece of wood $(60 \mathrm{~cm} \times 15 \mathrm{~cm}$ approx.) to which spines from the Cereus stenogonus (Cactaceae) cactus were affixed or, in recent years, as an innovation, a toothed metal plate was held in place with nails, cord or the fingers (Figure 3; Figure 6a, see next page). The wood used could be Stetsonia coryne (Cactaceae) or Salta triflora (Polygonaceae).

The Lengua-Maskoy used to prepare it by longitudinal sectioning the Stetsonia coryne stem (40 cm $\times 15 \mathrm{~cm}$ approx. with its rounded ends), from which the fleshy and soft tissues surrounding the core wood were separated and, while still fresh, large stiff spines from another cactus, Cereus stenogonus (Figure 6b, Figure 7, see next pages), were embedded perpendicularly.

Interviews conducted among the Nivaclé revealed that there were two forms of preparing graters. One form consisted of a flat piece of "palo santo" (Bulnesia sarmientoi, Zygophyllaceae) or of "coronillo" wood (Schinopsis lorentzii, Anacardiaceae), with a furrowed surface carved on one of its sides (Figure $6 \mathrm{f}$ and $6 \mathrm{~g}$ ). Once access to metals was available, another way of making the grater 


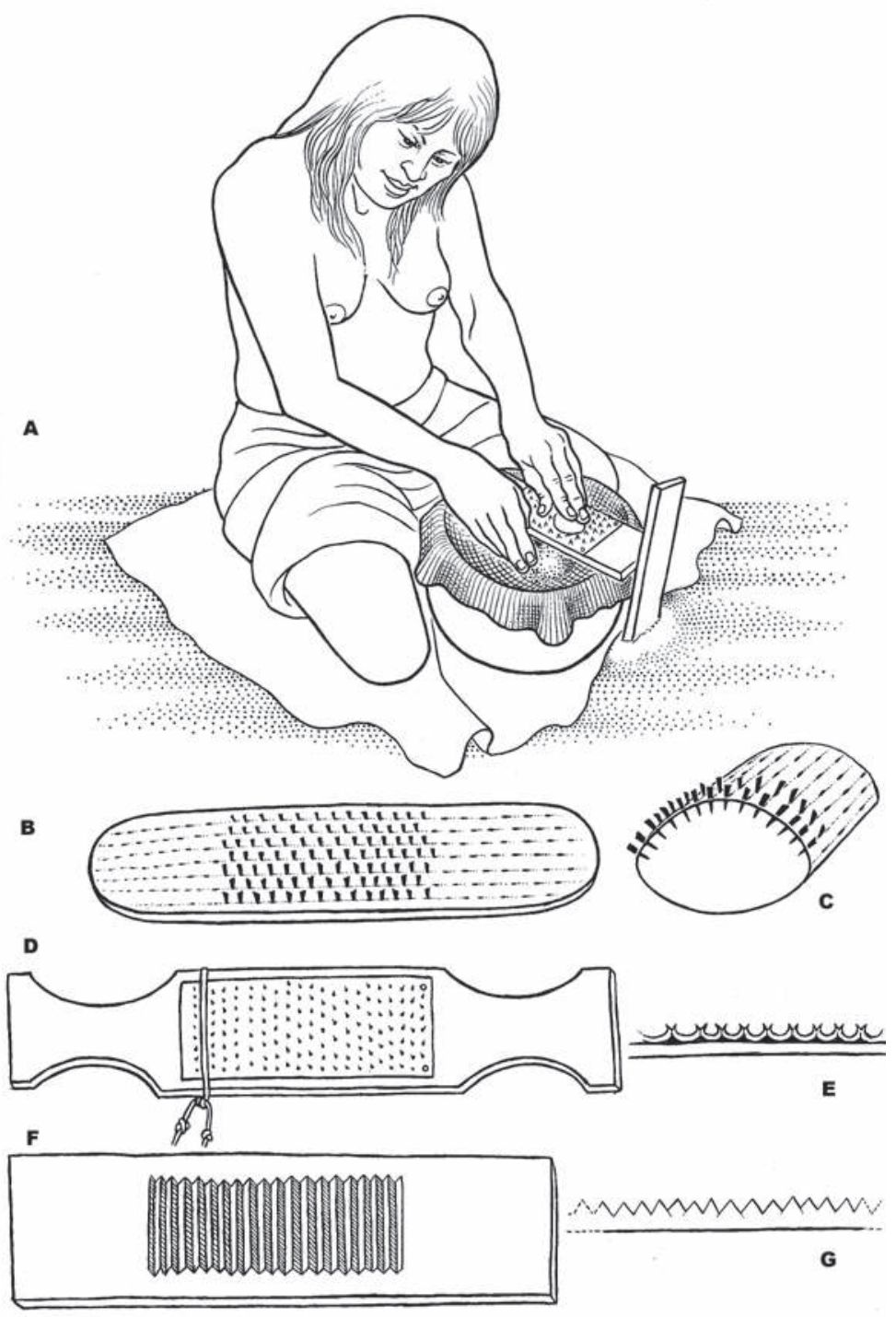

Fig. 6 - a. Technique used in grating "bitter" manioc root. Graters: b. Flat piece of wood with embedded spines; c. Crosssection of Stetsonia coryne wood with embedded spines; d. Flat piece of wood with toothed metal plate, held in place with nails and cord; e. Profile of previous figure; f. Flat piece of wood with furrowed surface; g. Profile of previous figure. 


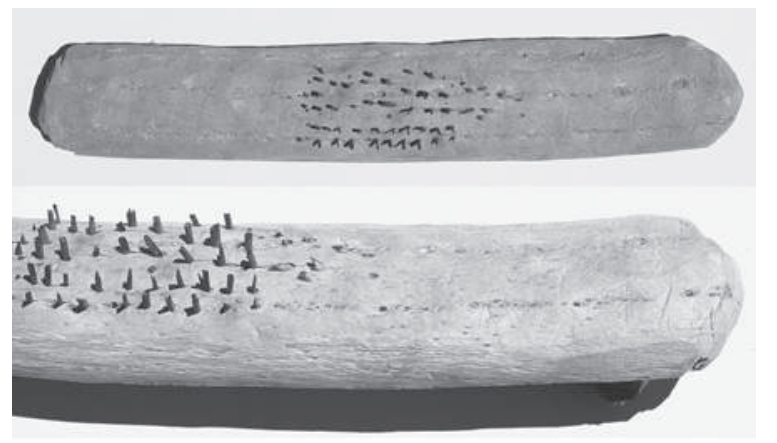

Fig. 7 - Lengua-Maskoy grater of Stetsonia coryne wood with spines of Cereus stenogonus embedded (Misión Nueva Vida, Paraguay, XI-1977, photographer: P. Arenas).

was to section the "tuna" wood stem (Stetsonia coryne), preparing a board, over which a previously perforated metal plate or tin was placed. When in use it was held in place with a fiber cord (Bromelia urbaniana) or with nails (Figure 6d and 6e).

Among the Maká, the "bitter" manioc grater could be prepared with a piece of "palo mataco" or "karandá" wood (Prosopis kuntzei, Fabaceae), on which furrows were made on one of the sides. If this raw material was unavailable, "palo santo" wood (Bulnesia sarmientoi) was used (Figure 6f and 6g). This model is very similar to that used by the Nivaclé. The Maká also used Stetsonia coryne wood; the fleshy outer layers were removed, and spines from a Gleditsia amorphoides (Fabaceae) trunk were embedded perpendicularly. Preferably a piece of wood (complete, without longitudinal section) was used because the result was more resistant; the wood was cut in half only if it split during preparation (Figure $6 \mathrm{~b}$ and $6 \mathrm{c}$ ). The wood of this cactus was thought to be suitable for spines to be embedded. Another possibility consisted in placing a toothed metal plate above the piece of wood.

\section{Graters observed in ethnographic museums}

As noted above, in the Museo Etnográfico "Juan B. Ambrosetti" (Buenos Aires) two manioc graters of Nivaclé origin were observed. They were from two separate sites located on the Pilcomayo River in Paraguay. In the museum's documentation there are no references to the raw materials used. Both pieces are longitudinal sections of wood that have a perforated plate on one side that is attached with nails, although on one of them the plate is held in place by a fiber cord. In one of the pieces the wood used seems to be from a palm tree (Figure 8a, see next page), as the foliar scars can still be seen. It is almost certainly a stem of Copernicia alba (Arecaceae), which is the only palm that grows in the region. On the other hand, the wood in the other piece is lighter and better worked, which would indicate that it could be from the Stetsonia coryne cactus (Figure $8 \mathrm{~b}$ and $8 \mathrm{c}$ ). These two pieces are remarkable for having 


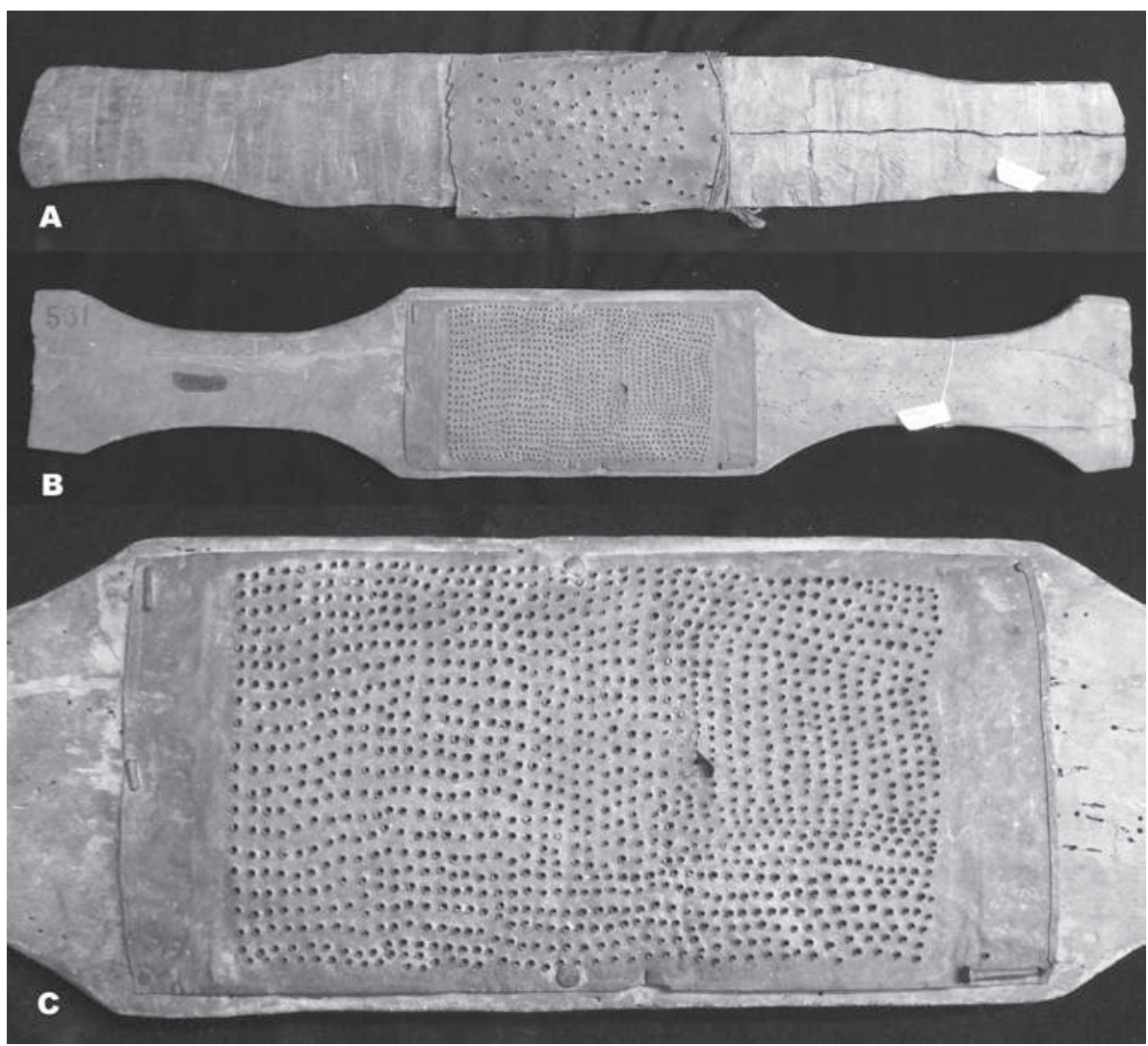

Fig. 8 - Nivaclé graters. a. Piece of Copernicia alba (?) wood with toothed metal plate; b. Piece of Stetsonia coryne (?) wood with toothed metal plate; c. Detail of toothed metal plate (photos courteously provided by the Ethnographic Museum "Juan B. Ambrosetti”).

both ends shaped as handles, as seen among the Karajá (Mato Grosso, Brazil)² and in the material compiled by Nordenskiöld.

A grater made by the Ashlushlay (Nivaclé) from Los Esteros on the Pilcomayo River, Paraguay, may be seen at the Göteborgs Etnografiska Museum

2. Similar pieces made by the Karajá in Mato Grosso (Brazil) consist of a wooden board with palm spines embedded in the center. Both ends are slightly narrowed to form two handles. They are housed at the Göteborgs Etnografiska Museum (No. 1961.18.0110, Göteborg), the Weltmuseum (No. 139.269/270/271, Vienna) and the Museum der Kulturen (No. 15649, Basel), although in the latter there is no indication as to what material is employed for the teeth of the grater. Although these pieces do not belong to ethnic peoples of the Gran Chaco, certain typologies coincide in various aspects with those found in the region studied. 
(No. 13.1.488). The base is of palm wood and its ends are narrowed like two handles. In its center there are wooden chips that act as teeth. The plant from which they were taken is not specified (Nordenskiöld 1929a, p. 90).

A Lengua-Maskoy manioc grater from the early years of the 20th century (it entered the museum in 1908, No. 1908.25.3) was also observed at the Pitt Rivers Museum (University of Oxford). It is a carved rectangular piece of wood $(62.2 \mathrm{~cm} \times 10 \mathrm{~cm})$ and its label says: "the wood is obtained from one of the giant cactus trees and the spines are from a palm tree." The tree cactus is undoubtedly the Stetsonia coryne and the spines are certainly from the seed pod of the Trithrinax schizophylla (Arecaceae) palm tree. In our investigation we found no references as to this palm tree being used for the grater, but it was documented as forming the teeth of the stick comb (Arenas 1981, p. 80). We were informed that the Lengua-Maskoy, who also used toothed metal plates on Stetsonia coryne wood, have given up the use of spines embedded in wood in manufacturing tools.

In the Museum der Kulturen (Basel) there is a Nivaclé grater from Paraguay (No. 16166), measuring $60 \mathrm{~cm} \times 11 \mathrm{~cm}$. It is made of cactus wood (Stetsonia coryne) and is longitudinally sectioned in the middle; in the center there is a toothed metal plate of $30 \mathrm{~cm}$ in length that covers the upper side and envelops the wood almost completely underneath, where it is held in place by nails.

\section{Typology of manioc graters in South America}

This paper takes as its starting point the work done by Nordenskiöld (1929a, p. $90-91$; 1929b, p. 276, 295, fig. 1). He offers a historical analysis based on bibliographic sources and close observation of pieces, and he outlines the following typological summary: 1) spiny rachis from a palm tree; 2) chips of wood set on a wooden board; 3 ) stones set on a wooden board; 4) other types that the author also takes from bibliographic sources. Here he mentions stone, wood or pottery graters with a surface that either resembles a rasp or is set with fish bones or teeth (although he does not specify their origin), which could suggest a broader and more varied typology.

In order to relate the graters of the Gran Chaco to similar pieces from other regions of South America, observations were made in various museum collections. The specific information gleaned from bibliographic sources was also taken into account (Roth 1924, p. 277-278; Nordenskiöld 1929a, p. 90-92; Lowie 1948, p. 6; Oberg 1953, p. 21, 72; Baldus 1970, p. 241; Susnik 1982, p. 93; Ribeiro 1988, p. 271; Albert and Milliken 2009, p. 40-41). Consultations in museum collections from South America (see Methodology) under the key word "manioc grater" produced 131 results. This paper discusses only 78 samples that serve to exemplify the different types or models. It does not discuss the 53 remaining results, either because the information on the raw 
material contains imprecisions or because its use for grating manioc is not specified. The result is an extension of the typological synthesis put forward by Nordenskiöld (1929a, p. 90-92), which seeks to show the diversity of raw materials used in South America, and not to reflect standardized types of grater in terms of morphology or dimensions:

1) Wooden board with a furrowed carved portion (Figure $6 f$ and $6 g$ ); 2) wooden base with teeth of: a) wood, b) stone or c) pieces of metal (Figure 6b and 6c); 3 ) wooden base with perforated metal plate (Figure 6d and 6e);4) spiny rachis from a palm tree; 5) piece of pottery with a furrowed surface; 6) pottery base with stone teeth; 7) piece of stone with rough surface; 8) wooden base with: a) encrusted fish teeth or bones, b) pieces of shell.

\section{Discussions and conclusions}

Until the 1980s, the variety of manioc grown was barely mentioned in any of the bibliographic sources referring to the ethnic peoples of the Gran Chaco, nor were details provided as to the forms of preparation. The exception is a piece of information given by Métraux (1946, p. 251) that records that "bitter" manioc was grown by the Guaná, but no further details are provided, and neither is the source of information. This research reliably confirms the growing of "bitter" manioc by the Nivaclé, the Maká, the Lengua-Maskoy and the Choroti-Manjuy.

Throughout the 20th century, very few anthropologists took the trouble to classify crops or provide details of the agricultural practices of the ethnic communities of the Gran Chaco, however small. Nevertheless, during the ethnobotanical campaigns still being conducted in the 1970s and 1980s it was observed that "bitter" manioc continued to be grown. It frequently existed alongside "sweet" manioc, which had been adopted after contact with the Criollo people. It is even stranger that Nordenskiöld (1912, p. 56; 1929a, p. 90) alone documents and refers to the manioc grater in the Gran Chaco. The absolute lack of subsequent data and the scarcity of pieces in ethnographic museums are also alarming since as late as 1981 the grater was still being used by the Manjuy, and one of us (Arenas) even had the chance to observe the preparation of, and to eat, manioc bread. One Nivaclé family still owned a manioc grater in early 2014, although it was not in use. The varieties of manioc recognized as "bitter" or "poisonous" by the ethnic groups of the Gran Chaco are prepared as described in this article. This study restricts itself to the forms in which these varieties are cooked. Nevertheless, it should be stressed that different authors speak of the existence of a continuum as regards toxicity values (Renvoize 1972, p. 358; Rogers and Fleming 1973, p. 8; Boster 1985; Nye 1991). Apparently, this particular fact goes unnoticed among the ethnic groups which experience fear of possible food poisoning. 
The majority of the ethnic peoples of the Gran Chaco possibly no longer grow "bitter" manioc, although some families in more remote regions may occasionally continue to do so. However, we can affirm that even today, one aged Maká woman who assisted us still keeps a few plants that she tends more as a memory of the past than for actual use.

The form of preparation and consumption of "bitter" manioc, as well as the associated utensils, coincides between the different ethnic groups of the Gran Chaco. This is in contrast with the great variety of preparation and consumption techniques found in other indigenous and non-indigenous groups of the Neotropics (Goldman 1948, p. 772-773; Lowie 1948, p. 6; Galvão 1963, p. 127 131; Schwerin 1970, 1971; Glenboski 1983, p. 40; Ribeiro 1987, p. 302-303; Meggers 1989, p. 75-76, 134; Nye 1991; Elias et al. 2000; Koch-Grünberg 2005, p. 529-534). ${ }^{3}$

The use of manioc graters by the Choroti-Manjuy, the Lengua-Maskoy, the Nivaclé and the Maká is documented. There are just five graters from the Gran Chaco found in museums. The ethnobotanical information obtained through field interviews is, however, richer than the data recorded in the documentation that accompanies the objects belonging to the museum collections. In fact, it was only thanks to oral information that the way in which this utensil was used by the Maká in the past could be reconstructed. Among the Lengua-Maskoy and the Nivaclé, graters have been observed, although they are no longer used. Only among the Choroti-Manjuy was it possible to observe and document in situ the use of the grater and the complete preparation process (Figure 3 and 4).

Nordenskiöld (1929a, p. 90) alone presumes that a small group of Wichí also used such a tool. His observations were surely based on an extension of observations in the villages where these Indians lived alongside the Nivaclé (Ashlushlay) and the Choroti. Nevertheless, at no time does the extensive bibliography on Wichí material culture record the existence of the grater among this ethnic group (Schmidt 1937; Gonzalo 1998; Arenas 2003; Alvarsson 2012; Montani 2012; Suárez 2014). Basing himself on the information obtained by Nordenskiöld (1929a, p. 90), Métraux (1946, p. 264) mentions a manioc grater, but says that it is rare in the Gran Chaco, since it had been mentioned only by this author. Alfred Métraux mainly worked with the Wichí, the Toba and the Pilagá, as well as with the Guaraní of the Andean foothills; there are no records of these ethnic peoples using the grater, which explains his observation, as well as the absence of this instrument in the rich collections he formed. One of us (Arenas) specifically investigated the presence of this utensil among the

3. There are many references to the varieties of "bitter" and "sweet" manioc, and how the ethnic groups of South America prepare it. Steward (1946-1959) has compiled some excellent documentation in the seven volumes of the Handbook of South American Indians, which we refer as one of the best primary sources. 
Toba, the Pilagá and the Wichí, using drawings and photographs. In all cases the interviewees claimed to know nothing of the artifact. In the 1980s, the Choroti living on the banks of the Pilcomayo River were also studied. During his expeditions at the start of the 20th century, Nordenskiöld had worked with them and recorded that they used the grater. They also failed to recognize it from drawings and photographs, so they had surely completely discontinued its use several decades before. The Choroti-Manjuy used it up until a few years ago, as we indicate in the results. Nordenskiöld (1929a, p. 70-71) adds another detail that needs to be clarified: he states that the Nivaclé used a wooden saw to scrape the manioc roots. However, in their investigations among the ChorotiManjuy, Arenas et al. (1987-1988) found that the use of this wooden saw was not related to the consumption of the plant.

Until the dawn of the 20th century, most of the ethnic groups of the Gran Chaco were still semi-nomadic, and continued to be so for several decades more in places outside urban centers. This life of frequent movement helps to understand that the objects they used had to be easily transportable, and in fact many of them were manufactured at the moment of use and were later discarded. In the case of manioc graters, this coincides with observations, since those made with small metal plates could be mounted on a board for use; only the metal piece would then be kept, and the wooden base discarded. Access to metal plates was an undoubted benefit in lightening the load, and users effectively took advantage of the fact. Access to industrial materials facilitated the task by incorporating woods from boxes or discarded construction material or packaging. Pottery pieces and the use of stones as teeth on the grater posed problems in transporting them and in actually obtaining them. The pottery of the indigenous groups from the Gran Chaco was not of prime importance, and was mainly used in the typical plate or bowl, cooking pot and jug (Métraux 1946, p. 289-291; Serrano 1966, p. 142). In addition, the use of stones was even more limited, since in the Gran Chaco direct access to rocky material is only possible in the furthest reaches of the area. ${ }^{4}$ Wooden graters, especially those incorporating a metal plate, were those best adapted to material possibilities and to the way of life of the Gran Chaco indigenous peoples.

Another aspect worth noting is that the Gran Chaco graters observed lack ornamentation and it does not seem that their production involved any aesthetic input, unlike what can be observed in their other handmade work (network, engravings on gourds, pipes, etc.), in their body painting and tattoos, and so on. Perhaps the

4. Rocks may be obtained in only two locations. One is on the western border of the Gran Chaco, in the foothills of the Andes, and the other is in certain orographic formations in the north and north-east of the region, places to which few ethnic groups had access. The stones were obtained in exchanges or on journeys to the region, but they were always scarce and so were prized assets. 
lack of interest in adorning the grater indicates that it can easily be disposed of in view of the nomadic nature of these societies. This stands in contrast to graters from other parts of South America, which are larger and typical of sedentary societies, particularly those of Amazonia, where they are heavily ornamented.

Nordenskiöld (1929a, p. 90) suggested that the manioc grater used by the native groups of the Gran Chaco originally came from peoples of the north and east of South America, from tribes scattered throughout the Amazon region. After observation of the instruments made in the field, in museums and in bibliographic references, we agree with this point of view: the similarities are conclusive. However, with the comparative elements discussed in this paper the route by which the grater arrived in the Gran Chaco cannot be specified, nor can it be proved that the instrument is a legacy of the Arawak peoples living in the region, to whom the development of Gran Chaco agriculture is attributed. Historical and archaeological research may provide an answer to these questions.

Most of the graters reviewed in this paper are from on-line consultations of material on the websites of the respective institutions. Quality in terms of the images and data varied in all cases and conclusive interpretations cannot be made as regards the raw materials used. With the passage of time on-line catalogs will certainly improve and a more accurate analysis will thus be possible. *

* Manuscrit reçu en mai 2016, accepté pour publication en juillet 2017.

Acknowledgements - We would like to thank the very many persons from different ethnic groups who made themselves available for interviews on these subjects, and the curators of the ethnographic museums that put their facilities at our disposal and provided answers to our queries. Thanks are also due to Alfonsina Elías and Sebastián Cohen of Museo Etnográfico "Juan B. Ambrosetti," who allowed us to reproduce the images of the Nivaclé graters (Figure 8); to Leonid Velarde of the Musée d'ethnographie (Genève, Suisse); to Hannes Kalish (Campo Largo, Chaco, Paraguay), who collated data from the Lengua-Maskoy; to Francisco Silva Noelli (Universidad Estadual de Maringá, Brasil) for the bibliographic material he supplied; to Alejandra Filipov, María Eugenia Suárez, Didier Roguet and Lawrence Wheeler for their valuable assistance in the preparation and revision of the manuscript; and very especially to Francisco Rojas, who provided the drawings in Figure 6.

\section{References cited}

Albert Bruce and William Milliken

2009 Urihi a. A terra-floresta yanomami, Instituto Socioambiental, São Paulo. Allem Antonio C.

2002 "The origins and taxonomy of Cassava", in Rory J. Hillocks, J. Michael Thresh and Antony C. Bellotti (eds.), Cassava. Biology, production and utilization, CABI Pub., Wallingford/New York, p. 1-16. 
Alvarsson Jan-Åke

2012 Etnografía 'Weenhayek, Vol. 3. Belleza y utilidad. La cultura material, Universidad de Uppsala, Uppsala.

Arenas Pastor

1981 Etnobotánica Lengua-Maskoy, Fundación para la educación, la ciencia y la cultura, Buenos Aires.

1982 "Recolección y agricultura entre los indígenas maká del Chaco Boreal", Parodiana, 1 (2), p. 171-241.

1983 "Nombres y usos de las plantas por los indígenas maká del Chaco Boreal”, Parodiana, 2 (2), p. 131-229.

1995 "Encuesta etnobotánica aplicada a indígenas del Gran Chaco", Hacia una nueva carta étnica del Gran Chaco, 5, p. 161-178.

2003 Etnografía y alimentación entre los Toba-Ñachilamole\#eky Wichi-Lhuku'tas del Chaco Central (Argentina), P. Arenas, Buenos Aires.

Arenas Pastor, José A. Braunstein and Guido P. Galafassi

1987-1988 "La sierra de madera de los indígenas del Gran Chaco", Annals Aarstryck, Etnografiska Museum (Göteborg), 1987-1988, p. 21-30.

Azara Félix de

1904 Geografía física y esférica de las provincias del Paraguay, y misiones guaranies, Museo nacional (Anales del Museo nacional de Montevideo, Sección Histórico-Filosófica, 1), Montevideo.

BaLdus Herbert

1931 Indianerstudien im nordöstlidren Chaco, Verlag von C.L. Hirschfold, Leipzig.

1970 Tapirapé. Tribo tupí no Brasil Central, Companhia Editora Nacional, São Paulo.

BogGiani Guido

1900 Compendio de etnografía paraguaya moderna, Talleres Nacionales de H. Kraus, Asunción.

BóRmida Marcelo and Mario CALIFANO

1978 Los indios ayoreo del Chaco Boreal. Información básica acerca de su cultura, Fundación para la educación, la ciencia y la cultura, Buenos Aires.

BOSTER James Shilts

1985 "Selection for perceptual distinctiveness evidence from Aguaruna cultivars of Manihot esculenta", Economic Botany, 39 (3), p. 310-325.

Bradbury E. Jane, Anne Duputié, Marc Delêtre, Caroline Roullier, Alexandra NarváezTrujillo, Joseph A. Manu-Aduening, Eve Emshwiller and Doyle Mckey

2013 "Geographic differences in patterns of genetic differentiation among bitter and sweet manioc (Manihot esculenta subsp. esculenta; Euphorbiaceae)", American Journal of Botany, 100 (5), p. 857-866.

Braunstein José A. and Elmer S. Miller

1999 "Etnohistorical introduction", in Elmer S. Miller (ed.), Peoples of the Gran Chaco, Bergin and Garvey, Westport (CO), p. 1-22.

Cardus José

1886 Las Misiones franciscanas entre los infieles de Bolivia. Descripción del estado de ellas en 1883 y 1834, con una noticia de los caminos y tribus salvajes, una 
muestra de varias lenguas, curiosidades de historia natural y un mapa para servir de ilustración, Librería de la Inmaculada Concepción, Barcelona.

Chase SARdi Miguel

2005 "Economía nivaclé”, Suplemento Antropológico, Universidad Católica de Asunción, 40 (1), p. 171-265.

Cordeu Edgardo J. and Miguel DE Los Ríos

1982 "Un enfoque estructural de las variaciones socioculturales de los cazadoresrecolectores del Gran Chaco", Suplemento Antropológico, Universidad Católica de Asunción, 17 (1), p. 131-195.

Elias Marianne, Laura Rival and Doyle McKeY

2000 "Perception and management of cassava (Manihot esculenta Crantz) diversity among Makushi amerindians of Guyana (South America)", Journal of Ethnobiology, 20 (2), p. 239-265.

Elias Marianne, Gilda Santos Muhlen, Doyle McKey, Ana Carolina RoA and Joe Tohme

2004 "Genetic diversity of traditional South American landraces of cassava (Manihot esculenta Crantz): An analysis using microsatellites", Economic Botany, 58 (2), p. 242-256.

EMPERAIRE Laure

2000-2004 "La biodiversité agricole en Amazonie brésilienne : ressource et patrimoine", Journal d'agriculture traditionnelle et de botanique appliquée, 42 (1), p. 113-126.

Emperaire Laure, Pascale de Robert, Juliana SAntilli, Ludivine Eloy, Lúcia Van Velthem, Esther Katz, Claúdia López, Anne-Elisabeth Laques, Manuela Carneiro Da Cunha and Mauro Almeida

2008 "Diversité agricole et patrimoine dans le moyen Rio Negro (Amazonie brésilienne)", Les Actes du BRG, 7, p. 139-153.

GALVÃo Eduardo

1963 "Elementos básicos da horticultura de subsitência indígena", Revista do Museu Paulista, N. S., 14, p. 120-124.

GLENBOSKI Linda L.

1983 The ethnobotany of the Tukuna Indians Amazonas, Colombia, Universidad Nacional de Colombia (Biblioteca José Jerónimo Triana, 4), Bogotá.

Goldman Irving

1948 "Tribes of the Uaupes-Caqueta region", in Julian H. Steward (ed.), Handbook of South American Indians, vol. 3. The tropical forest tribes, Smithsonian Institution. Bureau of American Ethnology (Bulletin, 143-3), Washington, p. 763-798.

GonZALo Juan A.

1998 La cultura material de los mataco (mataco-maká) del Chaco Central, Centro Argentino de Etnología Americana (Colección Mankacén), Buenos Aires.

KERSTEN Ludwig

1968 Las tribus indigenas del Gran Chaco hasta fines del siglo XVIII. Una contribución a la etnografía histórica de Sudamérica, Edición Universidad Nacional del Nordeste, Facultad de Humanidades, Resistencia.

KISELA Vladimiro

1931-1932 “Tribu indígena maccá”, Revista de la Sociedad Cientifica del Paraguay, 3 (1), p. 43-49. 
KOCH-GRÜNBERG Theodor

2005 Dois anos entre os indígenas. Viagens no noroeste do Brasil (1903-1905), Editora da Universidade Federal do Amazonas, Facultade Salesiana Dom Bosco, Manaus.

Lowie Robert H.

1948 “The Tropical Forest. An Introduction”, in Julian H. Steward (ed.), Handbook of South American Indians, vol. 3. The tropical forest tribes, Smithsonian Institution. Bureau of American Ethnology (Bulletin, 143-3), Washington, p. 1-56.

Mashnshnek Celia O.

1989 "Las nociones míticas en la economía de producción de los ayoreo del Chaco boreal", Scripta Ethnologica, 8, p. 119-139.

MegGers Betty J.

1989 Amazonia, hombre y cultura en un paraíso ilusorio, Siglo XXI, México, $3^{\text {ra }}$ ed. MÉTraux Alfred

1946 "Ethnography of the Chaco", in Julian H. Steward (ed.), Handbook of South American Indians, vol. 3. The tropical forest tribes, Smithsonian Institution. Bureau of American Ethnology (Bulletin, 143-3), Washington, p. 197-370.

Montani Rodrigo M.

2012 El mundo de las cosas entre los wichis del Gran Chaco. Un ensayo etnolinguístico, unpublished Ph.D. thesis, Facultad de Filosofía y Humanidades, Universidad Nacional de Córdoba (Argentina).

NORDENSKIÖLD Erland

1912 La vie des Indiens dans le Chaco (Amérique du Sud), Delagrave (Revue de géographie, t. 6, fasc. 3), Paris.

1929a Études d'ethnographie comparée, I. Analyse ethno-géographique de la culture materielle de deux tribus indiennes du Gran Chaco, Les Éditions Genet, Paris.

$1929 \mathrm{~b}$ "The American Indian as an inventor", The Journal of the Royal Anthropological Institute of Great Britain and Ireland, 59, p. 273-309.

NyE Margaret M.

1991 "The mis-measure of Manioc (Manihot esculenta, Euphorbiaceae)", Economic Botany, 45 (1), p. 47-57.

OBerg Kalervo

1953 Indian tribes of northern Mato Grosso, Brazil, Institute of Social Anthropology (Publication, 15), Washington.

Palavecino Enrique

1948 Áreas y capas culturales en el territorio argentino, Editora Coni, Buenos Aires.

Peroni Nivaldo, Paulo Yoshio Kageyama and Alpina Begossi

2007 "Molecular differentiation, diversity, and folk classification of 'sweet' and 'bitter' cassava (Manihot esculenta) in Caiçara and Caboclo management systems (Brazil)", Genetic Resources and Crop Evolution, 54 (6), p. 1333-1349.

Renvoize Barbara S.

1972 "The area of origin of Manihot esculenta as a crop plant: a review of the evidence", Economic Botany, 26 (4), p. 352-360. 
RiBEIRo Berta G.

1987 "A arte de trançar: dois macroestílos, dois modos de vida", in Berta G. Ribeiro (ed.), Tecnologia indígena, Financiadora de Estudos e Projetos (Suma Etnológica Brasiliera, 2), Petrópolis, p. 283-321.

1988 Dicionário do artesanato indígena, Editora da Universidade de São Paulo, São Paulo.

Rival Laura and Doyle McKeY

2008 "Domestication and Diversity in Manioc Domestication and Diversity in Manioc (Manihot esculenta Crantz ssp. esculenta, Euphorbiaceae)", Current Anthropology, 49 (6), p. 1119-1128.

Rogers David J. and Henry S. Fleming

1973 "A monograph of Manihot esculenta with an explanation of the taximetrics methods used", Economic Botany, 27 (1), p. 1-113.

Rотн Walter E.

1924 "An introductory study of the arts, crafts, and customs of the Guiana Indians", Thirty-eighth Annual Report of the Bureau of American Ethnology to the Secretary of the Smithsonian Institution 1916-1917, U.S. Government Printing Office, Washington.

SAlick Jan, Nicoletta CELlinese and Sandra KNAPP

1997 "Indigenous diversity of Cassava: generation, maintenance, use and loss among the Amuesha, peruvian upper Amazo", Economic Botany, 51 (1), p. 6-19.

Santos Mühlen Gilda, Alessandro Alves-Pereira, Charles R. Clement and Teresa LOSADA VALLE

2013 "Genetic diversity and differentiation of brazilian bitter and sweet manioc varieties (Manihot esculenta Crantz, Euphorbiaceae) based on SSR molecular markers", Tipití. Journal of the Society for the Anthropology of Lowland South America, 11 (2), p. 66-73.

SchmedA-Hirschmann Guillermo

1998 "Etnobotánica ayoreo. Contribución al estudio de la flora y vegetación del Chaco. XI", Candollea, 53, p. 1-50.

SCHMIDT Max

1937 "Los guisnais”, Revista de la Sociedad Científica del Paraguay, 4 (2), p. 1-35.

1951 "Anotaciones sobre las plantas de cultivo y los métodos de la agricultura de los indígenas sudamericanos", Revista do Museu Paulista, 5, p. 239-255.

SCHWERIN Karl H.

1970 “Apuntes sobre la yuca y sus orígenes", Boletín Informativo de Antropologia, 7, p. 23-27.

1971 "The bitter and the sweet. Some implications of techniques for preparing manioc", paper presented at the 1971 Annual Meeting of the American Anthropological Association, New York.

Serrano Antonio

1966 Manual de la cerámica indígena, Ediciones Assandri, Córdoba, 2ed.

STAHL Wilmar

1982 Escenario indígena chaqueño pasado y presente, Asociación de Servicios de Cooperación Indígena-Mennonita, Filadelfia. 
Nicolás M. Kamienkowski and Pastor Arenas

STEWARD Julian H. (ed.)

1946-1959 Handbook of South American Indians, Smithsonian Institution. Bureau of American Ethnology (Bulletin, 143), Washington, 7 vols.

SuÁrez M. Eugenia

2014 Etnobotánica wichí del bosque xerófito en el Chaco Semiárido Salteño, Editorial Autores de Argentina, Don Torcuato (Argentina).

SusNik Branislava

1982 Los aborígenes del Paraguay, T. IV. Cultura Material, Museo Etnográfico Andrés-Barbero, Asunción.

VON Rosen Eric

1924 Ethnographical Research Work during the Swedish Chaco-CordilleraExpedition 1901-1902, C.E. Fritze Ltd., Stockholm.

Wilson Warren M. and Darna L. Dufour

2002 "Why 'bitter' cassava? Productivity of 'bitter' and 'sweet' cassava in a tukanoan indian settlement in the northwest amazon", Economic Botany, 56 (1), p. 49-57.

ZERRIES Otto

1968 "The South American Indians and their culture", in Ernst Josef Fittkau, Joachim Illies, Hans Klinge, Gerhard Helmut Schwabe and Harald Sioli (eds.), Biology and Ecology in South America, Dr. W. Junk N. V. Publishers, The Hague, p. 329-388. 